\title{
Üniversite Giriş Sınavlarındaki Coğrafya Sorularının Coğrafi Becerilere Göre Dağılımı
}

\author{
DOI: $10.26466 /$ opus. 827816 \\ * \\ Abdullah Türker* - Ufuk Sözcü ** \\ * Dr, Gazi Üniversitesi, Gazi Eğitim Fakültesi, Ankara/Türkiye \\ E-Posta: abdullahturker82@gmail.com \\ ORCID: $\underline{0000-0003-3839-2735}$ \\ ** Dr, Kastamonu Fen Lisesi, Kastamonu/Türkiye \\ E-Posta: $\underline{\text { usozcu@hotmail.com }}$ \\ ORCID: $\underline{0000-0002-6809-4774}$
}

\begin{abstract}
Öz
Bu çalışmada Coğrafya Dersi Öğretim Programı'nda (CDÖP) yer alan becerilerin üniversiteye giriş sınavlarındaki coğrafya sorular içerisinde nasıl yer bulduğunu tespit etmek amaçlanmıştır. CDÖP' te coğrafi becerilerin 2005 programı ile birlikte yer almasından dolayı 2005-2020 yılları arasındaki üniversite sınav sorular araştırmanın örneklemini oluşturmaktadır. Doküman inceleme modelinin kullanıldı̆̆g araştırmada veriler içerik analiziyle incelenmiştir. Ünivesite giriş sınavlarında çıkmış olan coğrafya soruları Ölçme, Seçme ve Yerleştirme Merkezi (ÖSYM)'nin web sitesi üzerinden ulaşılmıştır. Sinavlardaki coğrafya soruları araştırmacılar tarafindan tek tek incelenerek hangi beceri ya da beceriler ilişkili oldukları belirlenmiştir. Güvenirliğin alan uzmanları görüşleriyle sağlandığ çalışmada 583 coğrafya sorusu değerlendirilmiştir. Değerlendirme sonucunda soruların en çok coğrafi gözlem ve harita becerisini ölçtüğü görülmüştür. Bunun yanında zamanı algılama, kanıt kullanma ile değişim ve sürekliliği algılama becerilerini ölçen çok az sorunun olduğu, arazi becerisini ölçen hiç soru olmadığı tespit edilmiştir. Ayrıca soruların coğrafi becerileri eşit oranda ölçmediği, öğretim programında yer alan öğrenme alanı veya ünitelere göre de eşit oranda dağglmadı̆̆̆ dikkati çekmiştir. Ortaya çıkan sonuçlar neticesinde üniversite sınavında çıkan coğrafya sorularının öğretim programındaki becerilerle uyumlu bir şekilde hazırlanması gerektiği vurgulanmıştır.
\end{abstract}

Anahtar Kelimeler: Coğrafi beceri, coğrafya öğretim programı, üniversite sınav soruları 
ISSN: 2528-9527

E-ISSN : 2528-9535

Yıl Year: 11

Cilt Volume: 17

Sayı Issue: 35

Mart March 2021

Makalenin Geliș Tarihi Received Date. 18/11/2020 Makalenin Kabul Tarihi Accepted Date. 29/03/2021

\title{
Distribution of Geography Questions in University Entrance Exams by Geographical Skills
}

\begin{abstract}
In this study, it was aimed to determine how the skills in the Geography Curriculum (CDÖP) are included in the geography questions in the university entrance exams. Due to the fact that geographical skills are included in the CDÖP together with the 2005 program, university exam questions between 2005-2020 constitute the sample of the research. In the study using the document review model, the data were examined by content analysis. The geography questions from the university entrance exams were found on the website of the Assessment, Selection and Placement Center (ASPC). The geography questions in the exams were examined one by one by the researchers and it was determined which skill or skills they were associated with. 583 geography questions were evaluated in the study, where reliability was provided by expert opinions. As a result of the evaluation, it was observed that the questions measured the most geographical observation and map skills. In addition, it has been found that there are very few questions that measure time perception, evidence use, and change and continuity perception skills, and there are no questions that measure land skill. It was also noted that the questions did not measure geographical skills equally, nor were they equally distributed according to the learning area or units included in the curriculum. As a result of the results, it was emphasized that the geography questions that appeared in the university exam should be prepared in accordance with the skills in the curriculum.
\end{abstract}

Keywords: Geographical skill, geography curriculum, university exam questions. 


\section{Giriş}

Öğretim faaliyetleri ile öğrencilere kazandırılan kabiliyetler beceri olarak tanımlanabilir. Doğal ve beşeri ortam etkileşimini inceleyen coğrafya bilimi ile bireylerdeki mekân algısını üst düzeye çıkarmak için bazı becerilerin kazandırılması amaçlanmaktadır. 1994 yılında gerçekleştirilen Geography Education Standart Project (Coğrafya Eğitimi Standartları Projesi) kapsaminda coğrafi beceriler 1) coğrafi sorular sorma, 2) coğrafi bilgi edinme, 3) coğrafi bilgileri düzenleme, 4) coğrafi bilgileri analiz etme ve 5) coğrafi soruları yanıtlama olmak üzere beş başlık altında ifade edilmiştir. Olay ve olguların bulundukları yerde neden ve nasıl ortaya çıktıklarını düşünmek üzere coğrafi sorular sorma becerisinden faydalanılarak hipotezler geliştirilebilir. Coğrafi bilgi edinme becerisi; coğrafi veri toplama, saha çalışmaları, mülakatlar yapma ve arşiv tarama gibi faaliyetleri içerir. Coğrafi bilgilerin düzenlenmesi becerisi toplanan verileri yapısına uygun biçimde harita, tablo ve özetler oluşturarak düzenlemeyi içerir. Coğrafi bilgilerin analizi becerisi veriler arasında bağıntı kurma, ilişkiyi ortaya koyma ve coğrafi ilişkilere dair tahminler ortaya koyma süreçlerini içerir. Coğrafi soruları yanıtlama becerisine sahip bireylere ulaşabilmek için ilk dört becerinin iyi gelişmiş olması gerekir. Bu beceri ile bilgiyi analiz etme ve açıklamalar yaparak sonuçlara ulaşma yeteneğinin gelişmesi beklenir (Huynh, 2009).

Coğrafi beceriler, Ünlü (2011) ile Bozyiğit ve Akça (2017) tarafından ana hatları ile "Coğrafya dersi öğretim süreci boyunca öğrencilerde kazandırılması ve geliştirilmesi amaçlanan kabiliyetler" olarak tanımlanmaktadır. Artvinli (2010) ise tüm öğretim programlarında yer alan bu becerileri öğrencilerin yaşamlarında, mesleklerinde ve gelecekte de kullanabilmeleri için öğrenmeleri esas olan yetenekler olarak değerlendirmektedir.

1923'ten günümüze coğrafya dersi öğretim programlarının gelişimi ve değişimi incelendiğinde 2018 yılında yapılan değişikliğin onuncu değişim olduğu görülür (Kaya, 2012). Coğrafya dersi öğretim programları (CDÖP) incelendiğinde coğrafi beceri kavramı ilk kez 2005 CDÖP'te kullanılmıştır. 2005 CDÖP'ün genel yapısına bakıldığında süreç ve beceri temelli bir yapıda olduğu görülür. CDÖP'te verilen kazanımlara becerilerin kazandırılabilmesi için kılavuz görevi yüklenmiştir (Artvinli, 2010).

CDÖP'teki coğrafi beceriler; öğrencilerin günlük ve gelecek yaşamlarında ve hangi meslek grubunda görev yaparlarsa yapsınlar mesleki yaşamla- 
rında kullanabilecek niteliktedir. Belirtilen beceriler coğrafya konularının tümünde farklı düzeylerde kullanılabilir durumdadır ve coğrafya öğretimi sırasında kazanımların ilişkili olduğu ve gerektirdiği coğrafi becerilerin birlikte verilmesi gereklidir (Ünlü, 2014).

2018 CDÖP'te verilen beceriler ile kapsamları hakkında kısa açıklamalara aşağıda yer verilmiştir.

“Coğrafi Gözlem Becerisi: Gözlem becerisi; olay ve olgulara dikkat etme, olay ve olguları algılama, tanımlama, olay ve olguların neden ve sonuçlarını açıklama, olay ve gözlemlediklerinin nedenlerini sorgulayıp sonuçlarını tahmin edebilme, olay ve olgular arasında ilişkiler kurabilme, olay ve olguların benzer ve farklı yönlerini ortaya koyma, gözlediklerini kaydetme ve aktarma, gözlemlediklerini daha önce öğrendikleri ile karşılaştırabilme ve bağdaştırabilme, gözlediklerini araştırmalarında veya gelecekle ilgili planlamalar yapmak için kullanabilme, benzer olaylarla ilişkilendirme ve tekrar aynı olayla karşılaştığında ne yapması gerektiğine yönelik davranış geliştirme ile ilgilidir. Okul ve çevre şartlarının elverdiği ölçüde çevre gezileri ve alan çalışmaları düzenlenmesi, gözlemlemeye dayanan araştırma çalışmaları planlanması ve uygulanması bu becerinin geliştirilmesine katkı sağlayacaktır (MEB,2018)."

"Arazide Çalışma Becerisi: Bu becerinin gelişmesi için sınıf dışında yapılan ve coğrafya dersi için bilimsel laboratuvar çalışmaları niteliğinde olan arazi çalışmalarına yer verilmesi önemlidir. Öğrencilerin sınıf dışında çevresinde olup biten olay ve olguları gözlemlemeleri için teşvik edecek çalışmanın amaçlarını belirleme, araştırma için plan tasarlama (araştırma öncesi gerekli kaynak, malzeme toplama, takvimlendirme, arazide gerekli olan materyali hazırlama), gerekli araç-gereç ve teknolojiyi kullanma, arazide veri toplama ve kaydetme, verileri analiz etme, sonuçlar çıarma, öneriler geliştirme, rapor yazma gibi uygulamaları gerçekleştirebilecekleri çalışmalara ve projelere yer verilmesi bu becerinin gelişimine katkı sağlayacaktır (MEB,2018)."

“Coğrafi Sorgulama Becerisi: Coğrafi sorgulama becerisi; konu veya problemin farkına varma, konu veya problemi tanımlama ve açılama, konu veya problemi analiz etme ve yorumlama, gelecekle ilgili tahminlerde bulunma ve karar verme, kişisel çıkarımlarda bulunarak değerlendirmeler yapma ve yargilara varma süreçlerini içermektedir (MEB, 2018)." 
“Zamanı Algılama Becerisi: Doğa ve insana ait süreçler zamanla bir sistem ve doku oluşturur. Bu anlamda doğa ve insana ait süreçler açısından farklı zaman algıları vardır. Coğrafya dersi ile öğrencilere jeolojik süreçlere ait zaman algısı; yıllık, mevsimlik ve günlük süreçlerle ilgili zaman algısı; tarihî süreçler ile ilgili zaman algısı ve ekolojik döngüler ile ilgili zaman algısı kazandırılır (MEB, 2018)."

“Değişim ve Sürekliliği Algılama Becerisi: Değişim ve sürekliliği algılama; zaman ve süreç içindeki benzerlik ve farklılıkları bulmayı, mekândaki değişim ve sürekliliği algılamayı, coğrafi süreçlerdeki değişim ve sürekliliğin nedenlerini sorgulamayı gerektirir (MEB, 2018)."

"Harita Becerileri: Coğrafya öğretiminde harita çalışmaları oldukça önemlidir. Gerek arazi çalışmalarında gerekse sınıfta coğrafi olay ve olguların dağılışlarında haritalardan faydalanılır. Harita becerileri şunları içerir: Harita üzerinde konum belirleme, harita üzerine bilgi aktarma, amacına uygun harita seçme, haritalardan yararlanarak hesaplamalar yapma, mekânsal dağılışı algılama, haritayı doğru şekilde yorumlama, taslak haritalar oluşturma. Bununla birlikte küre ve atlas kullanma becerisi de coğrafi beceriler içerisinde yer alır. Küre ve atlas kullanma becerisi, temelde ilköğretim programlarında kazandırılan coğrafi beceridir (MEB, 2018)."

“Tablo, Grafik ve Diyagram Hazırlama ve Yorumlama Becerisi: Tablo, grafik ve diyagram hazırlama; uygun veri seçimi ve sınıflandırılması; verilere uygun tablo, grafik ve diyagram oluşturma, konuyla ilgili fotoğraflar kullanma ve ilişkilendirme; kesitler oluşturma (bitki ve jeoloji kesitleri gibi), tablo, grafik ve diyagramları uygun yerlerde kullanma; tablo, grafik ve diyagramları yorumlama; tablo, grafik ve diyagramları karşılaştırarak sentezleme becerilerini içerir (MEB, 2018)."

“Kant Kullanma Becerisi: Coğrafi olay ve olgularla ilgili doğa ve insan süreçlerine ait kanıtlar birincil, ikincil veya doğrudan araziden elde edilebilir niteliktedir. Coğrafyada kanıt kullanma “Jeolojik süreçlere ait fosil, taş veya tektonik vb. bir doğa unsurunu kanıt olarak kullanma; iklim süreçlerine ait kanit kullanma, tarihî, sosyal, ekonomik ve politik olay ve olgulara ait kant kullanma" becerilerini içerir (MEB, 2018)." 
Tüm bu beceriler birbiri ile ilişki içerisindedir. Doğal ya da beşeri çevrede var olan unsurların tespiti ve değişimi gözlem becerisini gerektirmektedir. Doğru şekilde gözlemlenen coğrafi ortam mekândaki değişim ve sürekliliği algılama ile zaman ve kronolojiyi algılama becerilerine alt yapı oluşturmaktadır. Çünkü CDÖP’e (2018) göre değişim ve sürekliliği algılama; zaman ve süreç içindeki benzerlik ve farklılıkları bulmayı, mekândaki değişim ve sürekliliği algılamayı, coğrafi süreçlerdeki değişim ve sürekliliğin nedenlerini sorgulamayı gerektirir. Çevre okuryazarlığı becerisi coğrafi ortamı doğru şekilde gözlemleyip bilgi, tutum ve davranış geliştirmeye katkı sağlamaktadır. Bu bağlamda Karatekin ve Aksoy (2012) öğrencilere ekoloji ve çevre bilgisi, çevre duyarlılığı, sorumlu çevre davranışı ve çevre sorunlarının çözümünde onlara bilişsel bir takım beceriler kazandırmanın önemine vurgu yapmışlardır.

Coğrafi becerilerin gelişebilmesi için öncelikle coğrafi bilgiye sahip olmak gerekmektedir. Coğrafi mekânlar arasında hareket etmek, bir yerden başka bir yere gitmek için nereye ve nasıl sorularına cevap bulabilmek coğrafi bilgi gerektirmektedir. Bu bilginin performansa dönüşüp kabiliyete dönüşmüş bir şekilde yapılması için coğrafi beceriye sahip olmak gerekmektedir. Coğrafi beceri coğrafi bilgi, tutum ve davranışı kapsayan bir niteliğe sahiptir. Ünlü (2011) insan ve doğa arasındaki ilişkinin yararlı bir şekilde gelişebilmesini coğrafi becerilerin gelişmiş olmasına bağlamaktadır. Coğrafi mekânı doğru anlamanın ve kullanmanın doğurduğu ihtiyaç neticesinde coğrafya öğrenmenin ve coğrafi becerileri geliştirmenin süreklilik arz ettiği anlaşılmaktadır. Kızılçaoğlu (2006), Dünya üzerindeki benzerlik ve farklılıkları ayırt edebilecek, sorunlara karşı duyarlı ve çözüm üretme potansiyeline sahip bireylerin yetiştirilebilmesinde coğrafi becerilerin kazand1rılmasının önemine vurgu yapmıştır. Taş (2008)'a göre ise coğrafi becerilere sahip öğrenciler çevre sorunları ve mekânsal sorunları daha iyi analiz edebileceklerinden, bireysel ve toplumsal daha iyi yaşam standartlarını yakalamak için coğrafi becerileri edinmiş bireylere ihtiyacımız vardır.

CDÖP'te yer alan becerilerin öğrencilere öğretim etkinlikleri ile kazandırılıp kazandırılmadığı okullarda yapılan dönem içi sınavlarla ölçülür. Ders öğretmeni tarafından yapılan sınavların yanında öğrencinin gelecekte yapacağı mesleği belirlemede büyük öneme sahip olan Ölçme, Seçme ve Yerleştirme Merkezi (ÖSYM) tarafından yapılan üniversiteye giriş sınavları da coğrafi becerilerin kazandırılma düzeylerini test etmede büyük öneme sahip 
sınavlardır. Literatür incelendiğinde coğrafi becerilerin kazandırılma düzeyleri, bunları etkileyen faktörler, öğretim programlarındaki beceri yaklaşımları, eğitim süreçlerinin coğrafi becerilerin kazandırılmasına etkisi, coğrafi becerilerin çeşitli değişkenler bakımından değerlendirilmesi gibi konularda çalışmalar olduğu görülmektedir (Koç, 2003; Shin, 2006; Taş, 2008; Artvinli, 2012: Alhosani ve Yagoub, 2015; Bozyiğit ve Akça, 2017; Ridha, Utaya, Bachri ve Handoya, 2019; Fesliyen, Şanlı ve Pınar, 2019).

ÖSYM tarafından yapılan çeşitli sınavlardaki coğrafya sorularının sayısal dağılışı, konulara göre dağılımı, düzeylerine göre dağılışı gibi birçok farklı açıdan incelendiği çalışmaların olduğu görülmektedir (Aladağ ve Duran, 2016; Sözen ve Türksever, 2019; Türksever ve Sözen, 2019; Kızılçaoğlu, 2004; Sözen ve Türksever, 2018; Özel, 2002). Ancak ÖSYM tarafından yapılan sınavlardaki soruların coğrafi becerileri ölçme düzeylerini belirlemeye yönelik bir çalışma olmadığı görülmüştür. Çalışmanın problemini üniversite sınavlarında sorulan coğrafya sorularının coğrafi becerileri ne düzeyde ölçtüğü sorusu oluşturmaktadır. Bu doğrultuda çalışmanın temel amacl; coğrafi becerilerin CDÖP'te yer almaya başladığı 2005 yılından 2020'ye kadar ÖSYM tarafından yapılan üniversiteye giriş sınavlarında (ÖSS-ÖYS / YGSLYS / TYT-AYT) sorulan coğrafya sorularının hangi coğrafi becerilerle ilişkili olduğunun belirlenmesidir.

\section{Yöntem}

\section{Araştırma Yöntemi}

Bu araştırmada doküman incelemesi modeli kullanılmıştır. Doküman analizi, basılı ve elektronik materyaller olmak üzere tüm belgeleri incelemek ve değerlendirmek için kullanılan sistemli bir yöntemdir. Nitel araştırmada kullanılan diğer yöntemler gibi doküman analizi de anlam çıkarmak, ilgili konu hakkında bir anlayış oluşturmak, ampirik bilgi geliştirmek için verilerin incelenmesini ve yorumlanmasını gerektirmektedir (Corbin ve Strauss, 2008; Akt. Kıral, 2020, s.173). Doküman incelemesi, araştırılması hedeflenen olgu veya olgular hakkında bilgi içeren yazılı materyallerin analizidir. Doküman incelemesinin aşamaları: dokümanlara ulaşma, özgünlük (orijinallik), kontrol etme, dokümanları anlama, veriyi analiz etme ve veriyi kullanmadır (Yıldırım ve Şimşek, 2013). 


\section{Evren ve Örneklem}

Araştırmanın evreni ÖSYM tarafından yapılan üniversite sınavlarındaki coğrafya sorularıdır. Araştırmanın örneklemini ise 2005-2020 yılları arasında ÖSYM'nin yayınladığı üniversite sınavındaki tüm coğrafya soruları oluşturmaktadır. Araştırmaya kapsamına alınacak sınavlar belirlenirken amaçsal örnekleme yöntemlerinden ölçüt örnekleme yönteminden yararlanılmıştır. Araştırmadaki ölçüt coğrafya dersi öğretim programında coğrafi becerilerin yer verilmeye başlandığı tarih ve sonrasıdır. Tablo 1 ölçüt örneklem dâhilinde seçilen yıllara ait coğrafya soru sayılarını göstermektedir.

Tablo 1. 2005-2020 yılları arasında üniversite sınavlarnda çıkan coğrafya soru sayıları.

\begin{tabular}{lllllllll}
\hline Yillar & 2005 & 2006 & 2007 & 2008 & 2009 & 2010 & 2011 & 2012 \\
\hline Soru Sayilart & 16 & 25 & 25 & 25 & 25 & 54 & 54 & 54 \\
\hline Yillar & 2013 & 2014 & 2015 & 2016 & 2017 & 2018 & 2019 & 2020 \\
\hline Soru Sayilart & 50 & 50 & 50 & 50 & 50 & 22 & 22 & 22 \\
\hline
\end{tabular}

\section{Verilerin toplanması ve Analizi}

Örneklem dâhilinde belirlenen yıllara ait sorular ÖSYM'nin resmi sitesinden elde edilmiştir. 2005-2020 yılları arasında yayımlanan 594 coğrafya sorusunun tamamına ulaşılmıştır. Ulaşılan sorular içerik analizi tekniği ile analiz edilmiştir. Veriler dört aşamada analiz edilmiştir. Bu aşamalar: 1) Listeleme aşaması, 2) Tasnif etme aşaması, 3) Kategori geliştirme, 4) Geçerliği ve güvenirliği sağlama aşamasıdır. Öncelikle sorular yıllara ve birinci-ikinci basamak sınavlarına göre sıralanmıştır. CDÖP'te yer alan coğrafi beceriler listelenmiştir. Soruların hangi beceri veya becerileri ölçtüğü ve hangi öğrenme alanında (2005 CDÖP) veya ünitede (2018 CDÖP) olduğuna yönelik oluşturulan tablo üzerinde kodlamalar yapılmıştır. Kodlamalar araştırmacıların yanı sıra coğrafya eğitimi alanında uzmanlaşmış 2 akademisyen ile birlikte toplamda 4 kişi tarafından yapılmıştır. Yapılan kodlamalar daha sonra eşleştirilerek kodlamaların güvenirliği Miles ve Huberrman'ın (1994) kodlayıcılar arasındaki görüş birliği formülüne [P (Uzlaşma Yüzdesi \%) = [Na (Görüş Birliği)/ Na (Görüş Birliği) + Nd (Görüş Ayrıllğı)] X 100) göre hesaplanmış ve güvenirlik katsayısı .86 bulunmuştur. Bu değer yapılan kodlamaların güvenilir olduğuna işaret etmektedir. Aşağıda bir üniversite sorusuna ait analiz örneği verilmiştir. 
14. X noktası $20^{\circ}$ Doğu meridyeni ile $40^{\circ}$ Kuzey paraleli, Y noktası ise $10^{\circ}$ Doğu meridyeni ile $30^{\circ}$ Kuzey paraleli üzerindedir.

Bu koordinatlar göz önüne alındığında Y noktası, $X$ noktasına göre hangi yöndedir?
A) Güneybatı
B) Güneydoğu
C) Kuzeybatı
D) Kuzeydoğu

E) Doğu

\section{Şekil 1. ÖSS 2008 1. Basamak Coğrafya Sorusu}

Uzmanlar tarafından yukarıda verilen sorunun doğal sistemler alanında yer aldığı ve harita becerisini ölçtüğü tespit edilmiştir. Harita becerisinin seçilmesinde CDÖP'te yer alan 'Harita üzerinde konum belirleme, haritalardan yararlanarak hesaplamalar yapma' ifadeleri kaynaklık etmiştir. Bazı soruların birden fazla beceride yer alması durumunda aynı soru iki farklı beceriye dahil edilerek toplama katılmıştır.

\section{Bulgular}

Bu bölümde, araştırma problem ve alt problemleri kapsaminda elde edilen verilere ait bulgulara yer verilmiştir. Şekil 2 'de üniversite sınavlarının birinci basamağında sorulan coğrafya sorularının CDÖP'te yer alan coğrafi becerilere göre dağılımı gösterilmektedir.

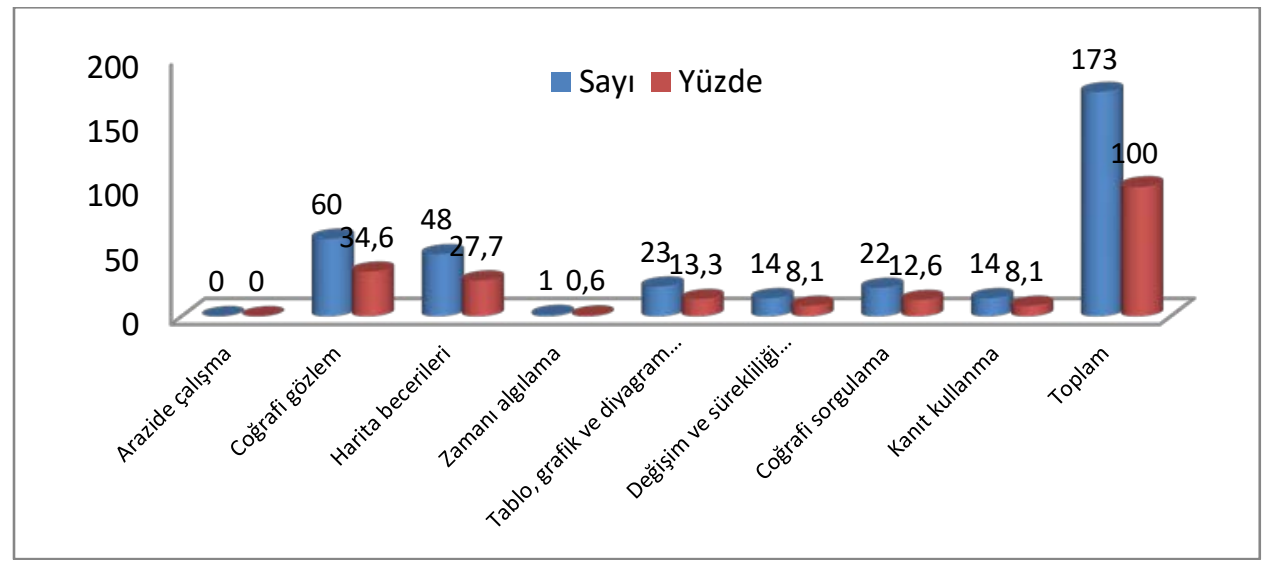

Şekil 2. Üniversite sınavlarındaki 1. Basamak Coğrafya Sorularının Coğrafi Becerilere Göre Dağılımı 
Üniversite sınavlarının birinci basamağında 2005-2020 yılları arasında 173 adet coğrafya sorusu sorulmuştur. Şekil 2 incelendiğinde bu soruların 60 tanesinin $(\% 34,6)$ coğrafi gözlem becerisini ölçmeye yönelik olduğu tespit edilmiştir. 48 sorunun $(\% 27,7)$ harita becerisini, 23 sorunun $(\% 13,3)$ tablo, grafik ve diyagram hazırlama ve yorumlama becerisini, 22 sorunun coğrafi sorgulama becerisini ölçmeye yönelik hazırlandığı görülmektedir. Zamanı algılama becerisine yönelik 1 sorunun olduğu coğrafya sorularında arazide çalışma becerisine yönelik soru bulunmadığı tespit edilmiştir. Şekil 3 'te üniversite sınavlarının ikinci basamağında sorulan coğrafya sorularının CDÖP'te yer alan coğrafi becerilere göre dağılımı gösterilmektedir.

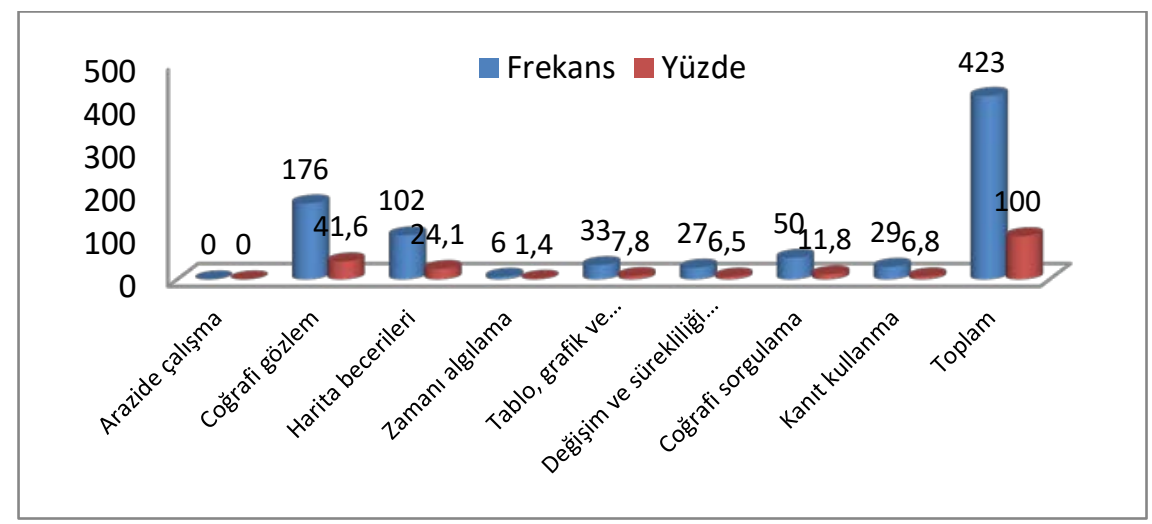

Şekil 3. Üniversite sinavlarnndaki 2. Basamak Coğrafya Sorularnnn Coğrafi Becerilere Göre Dağılımı

Şekil 3'te görüldüğü üzere bazı soruların birden fazla beceri içermesinden dolayı ikinci basamaktaki 404 olan soru sayısı tabloda frekans olarak 423 kabul edilmiştir. Bu sorulardan \%41,6'sı ( $\mathrm{f}=176$ ) coğrafi gözlem becerisini ölçmektedir. Coğrafi gözlemden sonra en fazla harita becerisini ( $\mathrm{f}=102)$ ölçen sorular yer almaktadır. Bu becerilere ek olarak 50 sorunun coğrafi sorgulama, 33 sorunun tablo, grafik ve diyagram hazırlama ve yorumlama, 27 sorunun değişim ve sürekliliği algılama becerisine yönelik olduğu görülmektedir. Zamanı algılama becerisinin 6 soru ile ölçüldüğü sorularda arazide çalışma becerisine yer verilmemiştir. Tablo 2 'de üniversite sınavlarında sorulan coğrafya sorularının temsil ettiği coğrafi becerilerin CDÖP'te yer alan öğrenme alanlarına göre dağılımı gösterilmektedir. 
Tablo 2. Üniversite sınavlarındaki coğrafya sorularnı ölçen coğrafi becerilerin CDÖP'te yer alan öğrenme alanlarına/ünitelere göre dağılımı

\begin{tabular}{|c|c|c|c|c|c|c|c|c|c|c|c|c|}
\hline \multirow[b]{2}{*}{ Coğrafi Beceriler } & \multicolumn{2}{|c|}{$\begin{array}{l}\text { Doğal } \\
\text { Sistemler }\end{array}$} & \multicolumn{2}{|c|}{$\begin{array}{l}\text { Beşeri } \\
\text { Sistemler }\end{array}$} & \multicolumn{2}{|c|}{$\begin{array}{l}\text { Mekânsal Bir } \\
\text { Sentez Türkiye }\end{array}$} & \multicolumn{2}{|c|}{$\begin{array}{l}\text { Küresel Ortam } \\
\text { Bölgeler ve Ülkeler }\end{array}$} & \multicolumn{2}{|c|}{$\begin{array}{l}\text { Çevre ve } \\
\text { Toplum }\end{array}$} & \multicolumn{2}{|c|}{ Toplam } \\
\hline & $f$ & $\%$ & $f$ & $\%$ & $f$ & $\%$ & $f$ & $\%$ & $f$ & $\%$ & $f$ & $\%$ \\
\hline Arazide çalışma & 0 & 0 & 0 & 0 & 0 & 0 & 0 & 0 & 0 & 0 & 0 & 0 \\
\hline Coğrafi gözlem & 39 & 18 & 54 & 24,9 & 51 & 23,5 & 33 & 15,4 & 40 & 18,4 & 217 & 37,2 \\
\hline Harita becerileri & 51 & 32,7 & 14 & 9 & 44 & 28,2 & 32 & 20,5 & 15 & 9,6 & 156 & 26,7 \\
\hline Zamanı algılama & 5 & 55,5 & 3 & 33,3 & 1 & 11,1 & 0 & 0 & 0 & 0 & 9 & 1,5 \\
\hline $\begin{array}{l}\text { Tablo, grafik ve diyagram } \\
\text { hazırlama ve yorumlama }\end{array}$ & 21 & 38,2 & 21 & 38,2 & 11 & 20 & 2 & 3,6 & 0 & 0 & 55 & 9,4 \\
\hline Değişim ve & & & & & & & & & & & & \\
\hline Sürekliliği algılama & 2 & 4,5 & 16 & 36,3 & 8 & 18,1 & 9 & 20,4 & 9 & 20,4 & 44 & 7,5 \\
\hline Coğrafi sorgulama & 8 & 10,5 & 25 & 32,9 & 24 & 31,5 & 4 & 5,2 & 15 & 19,7 & 76 & 13 \\
\hline Kanit kullanma & 10 & 21,7 & 12 & 26,1 & 13 & 28,2 & 9 & 19,5 & 2 & 4,3 & 46 & 7,9 \\
\hline Toplam & 132 & 22,6 & 135 & 23,1 & 146 & 25 & 89 & 15,2 & 81 & 13,9 & 583 & 100 \\
\hline
\end{tabular}

Tablo 2' de öğrenme alanlarına göre üniversite sınav sorularındaki coğrafi becerilerin dağılışı görülmektedir. Arazide çalışma becerisine ölçen bir kazanımın bulunmadığı görülmektedir. Coğrafi gözlem becerisine ait soruların daha çok beşeri sistemler $(\% 24,9)$ ve mekânsal bir sentez Türkiye $(\% 23,5)$ öğrenme alanlarında bulunduğu ancak genel olarak öğrenme alanlarına göre dengeli bir dağılıma sahip olduğu tespit edilmiştir. Coğrafi gözlem becerisine ait soruların toplam soruların \%37,2'sini oluşturarak en yüksek orana sahip olduğu da görülmektedir.

Harita becerilerini ölçen soruların çoğunlukla $(\% 32,7)$ doğal sistemler öğrenme alanında en az ise çevre ve toplum $(\% 9,6)$ ile beşeri sistemler $(\% 9)$ öğrenme alanında olduğu tespit edilmiştir. Harita becerilerine ait soruların toplam soruların \% 26,7'sini oluşturmaktadır. Zamanı algılama becerisini ölçen soruların toplam soruların \%1,5'ini oluşturarak en az orana sahip olduğu görülmektedir. Zamanı algılama becerisi sorularının \%55,5'i doğal sistemler öğrenme alanında yer alırken küresel ortam ülkeler ve bölgeler ile çevre ve toplum öğrenme alanında hiç soru olmadığı tespit edilmiştir.

Tablo, grafik ve diyagram hazırlama ve yorumlama becerisini ölçen soruların büyük çoğunluğunu $\% 38,2$ 'şer orana sahip olan doğal ve beşeri sistemler oluştururken çevre ve toplum öğrenme alanında herhangi bir soru tespit edilmemiştir. Bu becerinin toplam sorular içerisindeki oranı ise \% 9,4 olmuştur. Değişim ve sürekliliği algılama becerisinin toplam sorulardaki oranı $\% 7,5^{\prime}$ tir. Öğrenme alanlarına göre dağılımda beşeri sistemlerin $\% 36,3$ 
ile en yüksek orana sahip olduğu buna karşılık en az oranın $(\% 4,5)$ doğal sistemler öğrenme alanında olduğu görülmektedir.

Coğrafi sorgulama becerisine ait soruların en çok beşeri sistemler öğrenme alanında $(\% 32,9)$ en az küresel ortam ülkeler ve bölgeler $(\% 5,2)$ öğrenme alanında olduğu görülmektedir. Coğrafi sorgulama becerisinin toplam soruların \%13'ünü oluşturduğu tespit edilmiştir. Kantt kullanma becerisini ölçen soruların en çok mekânsal bir sentez Türkiye (\%28,2) öğrenme alanında en az da çevre ve toplum $(\% 4,3)$ öğrenme alanında yer aldığı görülmektedir. Kanıt kullanma becerisine ait sorular toplam soruların \% 9,7'sini oluşturmaktadır. Genel olarak becerilerin öğrenme alanlarına göre dağılımı incelendiğinde en çok becerinin mekânsal bir sentez Türkiye (\%25) öğrenme alanında, en az çevre ve toplum $(\% 13,9)$ öğrenme alanında yer aldığ1 görülmektedir. Öğrenme alanlarının soru dağılımının genel olarak birbirine yakın olduğu bulgusu da tespit edilmiştir.

\section{Tartışma}

2005-2020 yılları arasında üniversiteye giriş sınavının ilk aşamasında sorulan 173 sorunun \%34,4'ünün coğrafi gözlem, \% 27,7'sinin ise harita becerilerini test eden sorulardan oluştuğu görülmektedir. İkinci aşamadaki sınavlarda yer alan coğrafya sorularının becerilere dağılımına bakıldığında 423 sorudan \%41,6'sı ( $\mathrm{f}=176)$ coğrafi gözlem becerisini, \%24,1'nin ( $\mathrm{f}=102)$ ise harita becerisini ölçen sorular olduğu görülmektedir. Koç (2013) olay, olgu ve özelliklerin dağılışını haritalar yardımıyla gösterip neden-sonuç ilişkisi kurarak analiz edebilmek için harita becerilerine sahip olunması gerektiğini ifade etmiştir. Coğrafya branşı ile özdeşleşmiş ilkelerden olan dağılışın ortaya konulabilmesi için harita becerisine sahip olan bireylere ihtiyaç vardır. Bu bağlamda sinavlarda sorulan sorular içerisinde harita becerileri ile ilişkin soruların oranı iyi düzeydedir.

2018 CDÖP'te becerilerin ilişkilendirildiği kazanım sayılarına bakıldığında coğrafi sorgulama becerisi ile ilişkilendirilen kazanım sayısı 58, harita becerileri ile ilişkilendirilen kazanım sayısı 46, kanıt kullanma becerisi ile 32, değişim ve sürekliliği algılama becerisi ile 28, coğrafi gözlem becerisi ile 24, zamanı algılama becerisi ile 16, arazide çalışma becerisi ile 14 olduğu görülmektedir (MEB, 2018). CDÖP'teki kazanım-beceri ilişkilendirilmesinin 
dağılışı ile ilk aşamadaki sınav sorularındaki dağılımın tutarlı olmadığı görülmektedir.

ÖSYM tarafından yapılan üniversiteye giriş sınavlarında arazide çalışma becerisinin ölçülmesine imkân sağlayan sorular olmaması normal olarak değerlendirilmelidir. Çünkü arazide çalışma becerisinin kazanılıp kazanılmadığının kâğıt üzerinde ve özellikle çoktan seçmeli sorularda test edilmesi oldukça güçtür.

Üniversite giriş sınavlarındaki coğrafya sorularında \%37,2 ile en fazla ilişkilendirilen coğrafi gözlem becerisine ait soruların en fazla beşeri sistemler ünitesi ile ilişkili konularda sorulduğu görülmektedir. Bu durumun beşeri sistemler ünitesi başlı̆̆ı altında verilen konuları (nüfus, yerleşme, tarım, endüstri, ulaşım, turizm, ticaret gibi) günlük yaşamda gözlemlemenin daha kolay olması nedeniyle olduğu düşünülmektedir. Zira doğal sistemler ünitesi kapsamında özellikle yeryüzü şekilleri ile ilgili coğrafi gözlem becerisinin geliştirebilmek için arazi çalışmalarına ihtiyaç olabilecektir.

Coğrafyanın dağılış ilkesinin verilebilmesi için tüm coğrafya konularında sıklıkla tercih edilen haritaların okunması ve kullanılmasına yönelik becerilerle ilişkilendirilen soruların büyük oranda doğal sistemler ünitesi kapsamında olduğu görülmektedir. İklim ve yeryüzü şekillerini içeren konuların bu ünite kapsamında ele alınması nedeniyle bu durum normal olarak değerlendirilmektedir. Üniversite giriş sınavlarında temsil edilme oranı düşük olan zamanı algılama becerisi kapsamındaki soruların da yarıdan fazlasının doğal sistemler ünitesi kapsamında olduğu kapsamı dolayısıyla olağan bir durum olarak değerlendirilmektedir.

Tablo, grafik ve diyagram hazırlama ve yorumlama becerisi ile ilgili soruların doğal ve beşeri sistemler ünitelerinde yoğunlaşması normal karşılanabilir bir durumdur. Ancak çevre ve toplum ünitesi kapsamında hiç soruya yer verilmemiş olması eksiklik olarak değerlendirilebilir. Pala ve Başıüyük (2019) tarafından yapılan araştırmada tablo ve grafik okuma becerileri üzerinde matematik becerilerinin büyük etkiye sahip olduğu ortaya konulmuştur. Bu durum coğrafya soruları içerisinde tablo, grafik ve diyagram hazırlama becerisini ölçmek amacıyla kullanılan soruların çözümünde matematik becerilerine de ihtiyaç olduğunu ortaya koymaktadır.

Değişim ve sürekliliği algılama becerisi ile ilgili soruların beşeri sistemler ünitesinde yoğunlaştığ görülmektedir. Benzer biçimde coğrafi sorgulama becerisine ait soruların da büyük oranda beşeri sistemler başlı̆̆ı altındaki 
konularla ilintili sorulduğu görülmektedir. Bozyiğit ve Akça (2017) coğrafi sorgulama becerisinin kazanmış öğrencilerin nesne ve olayların yeryüzündeki konum ve dağılışlarını daha kolay algılayacağını vurgular.

Kanıt kullanma becerisini ölçen soruların ise 2005-2017 yılları arasında Mekânsal Bir Sentez: Türkiye öğrenme alanı kapsamındaki konularla ilişkilendirildiği görülmektedir. 2018 müfredatı ile birlikte Türkiye ile ilgili konuların diğer üniteler içerisinde verilmiştir. 2018 öncesindeki sınavlarda çıkan soruların Mekânsal Bir Sentez: Türkiye öğrenme alanı kapsamında sayıca fazla olması beceri-öğrenme alanı/ünite dağılımında üstünlük sağladığı görülmektedir.

\section{Sonuç ve Öneriler}

Araştırmada beceri temelli müfredatın uygulanmaya başlandığı 2005 yılından itibaren üniversiteye giriş sınavlarında çıkmış coğrafya sorularının ölçtüğü coğrafi becerilerin dağılımı incelenmiştir. Araştırmanın sonucunda toplam sorular arasında en fazla coğrafi gözlem becerisi ile ilintili sorulara yer verildiği görülmektedir. Coğrafi gözlem becerisini hem birinci basamak hem de ikinci basamak sinavlarında harita becerisi ile takip etmektedir. Uygulanan sinavlarda arazide çalışma becerisini ölçmek amacıyla hiç soruya yer verilmediği görülmektedir. Bu beceri dışındaki 7 beceri arasında en az soru gelen beceri ise zamanı algılama becerisi olmuştur. Becerilerin öğrenme alanı / ünite bazındaki dağılımlarına bakıldığında ise Türkiye ile ilgili konulara ağırlık verildiği görülmektedir.

Bu sonuçlar ışığında araştırma sonucunda aşağıdaki öneriler geliştirilmiştir;

- Öğretim programlarındaki bilgilerin yanında kazandırılmasının önemi her fursatta vurgulanan becerilerin de üniversiteye giriş sınavı sorularında ölçülmesi ile ilgili daha iyi planlamalar yapılarak soru-beceri dağ1lımı öğretim programı dikkate alınarak belirlenmelidir.

- Araştırmacılar için ise ÖSYM tarafından yapılan diğer merkezi sınavlarda (KPSS ya da Kurum Sınavları gibi) yer alan coğrafya sorularının ilişkilendirilebileceği becerilerin analizine yönelik çalışmalar yapılabileceği önerilmektedir. 


\title{
EXTENDED ABSTRACT
}

\section{Distribution of Geography Questions in University Entrance Exams by Geographical Skills}

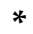

$*$

\author{
Abdullah Türker - Ufuk Sözcü \\ Gazi University, Kastamonu Science High School
}

\begin{abstract}
Abilities acquired by students through teaching activities can be defined as skill. It is aimed to gain some skills to maximize the perception of space in individuals through the science of geography, which studies the interaction of natural and human environments. In 1994, the Geography Education Standard Project (Geography Education Standards Project) geographic skills were expressed under five headings: 1) asking geographic questions, 2) obtaining geographic information, 3) organizing geographic information, 4) analyzing geographic information, and 5) answering geographic questions.. Hypotheses can be developed by using the ability to ask geographical questions to consider why and how events and phenomena occur where they are located. The ability to obtain geographic information includes activities such as collecting geographic data, field studies, conducting interviews and scanning archives. Ability to organize geographic information includes editing the collected data by creating maps, tables and summaries in accordance with its structure. Ability to analyze geographic information includes the processes of correlating data, revealing relationships, and making predictions about geographical relationships. In order to reach individuals who have the ability to answer geographical questions, the first four skills must be well developed. With this skill, the ability to analyze information and achieve results by making explanations is expected to develop (Huynh, 2009).
\end{abstract}

Geographical skills are defined by Ünlü (2011) and Bozyiğit and Akça (2017) as "skills intended to be acquired and developed by students during the geography course teaching process". Artvinli (2010), on the other hand, evaluates these skills contained in all educational programs as abilities that are essential for students to learn so that they can use them in their lives, professions and in the future. 
Examining the development and change of geography course curriculum from 1923 to the present, it is seen that the change made in 2018 is the tenth change (Kaya, 2012). The concept of geographical skills was first used in the 2005 GCC when geography course curriculum (GCC) was examined. Looking at the general structure of the 2005 GCC, it is seen that it has a process and skill-based structure. In order to gain skills in the achievements given in GCC, a guide task has been installed (Artvinli, 2010). Geographic skills included in the 2018 GCC; Geographical observation, working in the field, geographical inquiry, time perception, change and continuity perception, map skills, table, chart and diagram preparation and interpretation, and evidence use skills are collected under eight headings.

The problem of the study is to what extent the geography questions asked in university exams measure geographic skills. The main aim of the study in this direction is to determine which geographical skills are related to the geography questions asked in the university entrance exams (ÖSSÖYS / YGS-LYS / TYT-AYT) conducted by student selection and placement center from 2005 to 2020, when geographical skills began to be included in the GCC.

The document review model was used in this research. Document analysis is a systematic method used to examine and evaluate all documents, including printed and electronic materials. Like other methods used in qualitative research, document analysis requires the study and interpretation of data to make sense, create an understanding of the relevant topic, and develop empirical knowledge (Corbin \& Strauss, 2008; as cited in Kral, 2020, P.173). Document review is the analysis of written materials that contain information about the facts or facts that are intended to be investigated. Document review stages include access to documents, authenticity (authenticity), control, understanding documents, analyzing data and using data (Yildirim and Şimşek, 2013).

Questions for the years determined within the sample were obtained from the Official Site of the student selection and placement center. All 594 geography questions published between 2005-2020 have been reached. The questions reached were analyzed using the content analysis technique. The data was analyzed in four stages. These stages are: 1) listing stage, 2) sorting stage, 3) category development, 4) ensuring validity and reliability. First, the questions are sorted by year and first-and second part exams. The geograp- 
hic skills included in the GCC are listed. Encodings were made on the created table for what skills or skills the questions measured and in what learning area (2005 GCC) or unit (2018 G). Coding was done by researchers, as well as 2 academics specializing in geography education, and a total of 4 people. The codes are then matched and the reliability of the encodings is determined by Miles ands ccording to Huberrman's (1994) consensus formula between coders [P (Percentage of Agreement\%) $=[\mathrm{Na}$ (Consensus) / $\mathrm{Na}$ (Consensus) $+\mathrm{Nd}$ (Disagreement)] X 100) and yhe reliability coefficient was found to be 86 .

173 geography questions were asked between 2005-2020 in the first part of the university exams. It was found that 60 (34.6\%) of these questions were aimed at measuring geographical observation skills. 48 problems $(27.7 \%)$ were prepared to measure map skills, 23 problems (13.3\%) were prepared to measure table, graph and diagram preparation and interpretation skills, and 22 problems were prepared to measure geographical inquiry skills. It was found that there were no questions about the ability to work in the field in geography questions, where there was 1 question about the ability to perceive time. Figure 3 shows the distribution of geography questions asked at the second part of the university exams according to the geographical skills contained in the GCC.

Because of the skill of some of the questions in the second stage of the university exams, the number of questions, which was 404, was accepted as a frequency of 423 in the table. Of these questions, $41.6 \%$ ( $f=176)$ measure the ability to observe geography. After geographical observation, there were questions that measured the map skills ( $\mathrm{f}=102)$. In addition to these skills, it was seen that 50 problems were related to geography inquiry, 33 problems were related to the ability to prepare and interpret tables, graphs and diagrams, and 27 problems were related to the ability to perceive change and continuity. In the questions in which the ability to perceive time was measured by 6 questions, the ability to work in the field was not included.

Looking at the distribution of geographical skills in university exam questions according to learning areas and units, it seemed that there was no gain that measured the ability to work in the field. It was found that questions about geographical observation skills were mostly found in human systems (24.9\%) and spatial synthesis Turkey (23.5\%) learning areas, but had a balanced distribution according to learning areas in general. It was also 
observed that questions related to geographical observation skill had the highest rate, accounting for $37.2 \%$ of the total questions. It was found that the questions that measured map skills were mostly (32.7\%) in the field of natural systems learning, at least in the field of environment and society $(9.6 \%)$ and human systems (9\%) learning.

Between 2005-2020, 34.4\% of the 173 questions asked in the first part of the university entrance exam were geography observation and $27.7 \%$ of the questions were for testing map capabilities. Looking at the distribution of 423 geography questions in the second part of the exams to their abilities, $41.6 \%$ ( $\mathrm{f}=176)$ had questions that measured geography observation ability, and $24.1 \%$ ( $\mathrm{f}=102)$ had questions that measured ISE map ability. $37.2 \%$ of the geography questions in the university entrance exams were most associated with the geography observation skill questions in the subjects related to the University of human systems.

At the end of the study, it seemed that among the general questions, questions related to the ability to observe the most geography were included. Geography followed observation skill with map ability in both first and second part of the exams. In the applied rxams, there were no questions to measure the ability to work in the field. Among the 7 skills other than this skill, the skill that came with the least questions was the ability to perceive time. Considering the distribution of skills on the basis of learning area / unit, issues related to Turkey were given priority.

\section{Kaynakça / References}

Aladağ, C. ve Duran, Y. (2016). 2011-LYS Coğrafya sorularının madde güçlüğü ve kavram yanılgısı yönünden analizi. İlköğretim Online, 15(4), 1425-1435. doi http://dx.doi.org/10.17051/io.2016.01994

Alsosani, N.M.D. ve Yagoub, M.M. (2015). Geographic skills: a case study of students in the United Arab Emirates, International Research in Geographical and Environmental Education, 24 (1). 95-102.

Artvinli E. (2010). Coğrafya derslerini yapılandırmak: Aksiyon (eylem) araştırmasına dayalı bir ders tasarımı. Marmara Coğrafya Dergisi, 21, 184-218.

Artvinli, E. (2012). Integrate geographic skills with active learning in geography: a case of Turkey. Journal of Research and Didactics in Geography (J-READING), 1, Dec., 2012. 43-50 DOI: 10.4458/1005-06. 
Bozyiğit, R. ve Akça, D. (2017). Coğrafya öğretiminde coğrafi sorgulama becerisinin öğrencilerin tutum ve başarıları ile öğrenmenin kalıcllğı üzerine etkisi. Selçuk Üniversitesi Sosyal Bilimler Enstitüsü Dergisi. 38. 72-85.

Fesliyen, Z., Şanlı, C. ve Pınar, A. (2019). Ortaöğretim öğrencilerinin harita beceri düzeylerine yönelik bir eylem araştırmass: Kulu örneği. Gelecek Vizyonlar Dergisi, 3(3). 9-23.

Huynh, N. (2009). The role of geospatial thinking and geographic skills in effective problem solving with GIS: K-16 Education. Theses and dissertations (Comprehensive). 1078. https://scholars.wlu.ca/etd/1078.

Karatekın, K., ve Aksoy, B. (2012). Sosyal bilgiler öğretmen adaylarının çevre okuryazarlık düzeylerinin çeşitli değişkenler açısından incelenmesi. Electronic Turkish Studies, 7(1), 1423-1438.

Kaya, N. (2012). Türkiye'de coğrafya eğitimi: Öğretim programları, öğretmen eğitimi ve ders kitaplar boyutu. Yayınlanmamış doktora tezi, Gazi Üniversitesi, Ankara.

Kıral, B. (2020). Nitel bir veri analizi yöntemi olarak doküman analizi. Siirt Üniversitesi Sosyal Bilimler Enstitüsü Dergisi, 8(15), 170-189.

Kızılçaoğlu, A. (2004). ÖSYM sinavlarında 1981-2002 sorulan coğrafya sorularının değerlendirilmesi. Balkesir Üniversitesi Sosyal Bilimler Enstitüsü Dergisi, 7(11) ,77-95.

Kızılçaoğlu A. (2006). İlköğretim birinci kademesinde coğrafya eğitimi ve öğretimi. Marmara Coğrafya Dergisi, 14. 82-106.

Koç, H. (2003). Harita beceri düzeyleri ile öğrenme stilleri arasındaki ilişkinin belirlenmesi üzerine bir inceleme. Uşak Üniversitesi Sosyal Bilimler Dergisi, 6(4). 17-32.

Miles, Matthew. B. ve Huberman, A. Micheal. (1994). An expanded sourcebook qualitative data analysis. Thousand Oaks, California: Sage Publications.

Milli Eğitim Bakanlığı (MEB). (2005). Coğrafya dersi öğretim programı (CDÖP). Ankara: Talim ve Terbiye Kurulu Başkanlığı.

Milli Eğitim Bakanlığı (MEB). (2018). Coğrafya dersi öğretim programı (CDÖP). Ankara: Talim ve Terbiye Kurulu Başkanlığ.

Özel, A. (2002). Üniversite sınavlarındaki coğrafya sorularının dağılımı ile liselerdeki coğrafya programının ders saat sayılarının ve ağırlıklarının karşılaştırılması. Marmara Coğrafya Dergisi, 5, 55-67.

Pala, Ş.M. ve Başbüyük, A. (2019). Matematik becerisinin sosyal bilgiler derslerindeki harita grafik ve tablo okuma becerilerine etkisi. Uluslararası Sosyal Bilgilerde Yeni Yaklaşımlar Dergisi. 3(1), 41-56. 
Ridha, S., Utaya, S., Bachri, S. ve Handoyo, B. (2019). Students' geographic skills in Indonesia: Evaluating learning material questions about gis using taxonomy of spatial thinking. Journal of Social Studies Education Research, 10(4), 266-287. November 11, 2020 from https://www.learntechlib.org/p/216561/ adresinden erişilmiştir.

Shin, E-K. (2006). Using geographic information system (GIS) to improve fourth graders' geographic content knowledge and map skills, Journal of Geography, 105(3), 109-120, DOI: 10.1080/00221340608978672

Sözen, E. ve Türksever, Ö. (2018). Üniversite giriş sınavlarında coğrafya soru sayısındaki değişikliğin bölgesel liderlik açısından önemli olan ortaöğretim coğrafya programına olası etkilerinin değerlendirilmesi. Uluslararası Liderlik Eğitimi Dergisi (ULED), 3(3), 1-12.

Sözen, E. ve Türksever, Ö. (2019). KPSS coğrafya öğretmenlik alan bilgisi testi (öabt) soru dağılımlarının incelenmesi. Türkiye Sosyal Araştırmalar Dergisi, 2019 Özel Sayısı, 73-84.

Taş, H. (2008). Coğrafi beceriler ve bunları öğrencilere kazandırma yolları. Doğu Coğrafya Dergisi, 13(20) , 45-58.

Türksever, Ö. ve Sözen, E. (2019). 2012-2018 yılları arasında KPSS lisans genel kültür testi coğrafya soru dağılımlarının incelenmesi. Türkiye Sosyal Araştırmalar Dergisi, 2019 Özel Sayısı, 85-96.

Ünlü M. (2011). Coğrafya derslerinde coğrafi becerilerin gerçekleşme düzeyi. Kuram ve Uygulamada Eğitim Bilimleri, 11(4). 2115-2172.

Ünlü M. (2014). Coğrafya öğretimi, Ankara: Pegem Akademi.

Yıldırım, A. ve Şimşek, H. (2013). Sosyal bilimlerde nitel araştırma yöntemleri. Ankara: Seçkin.

\section{Kaynakça Bilgisi / Citation Information}

Türker, A. ve Sözcü, U. (2021). Üniversite giriş sinavlarındaki coğrafya sorularının coğrafi becerilere göre dağılımı. OPUS-Uluslararası Toplum Araştırmaları Dergisi, 17(35), 1875-1894. DOI: 10.26466/opus.827816 